\title{
Effect of Trifolium alexandrinum extracts on the kidneys of diabetic rats: Biochemical and histological study.
}

\author{
Maisaa M. AL-Rawi \\ Biology Department, Girls College, Makkah, Saudi Arabia.
}

\begin{abstract}
:
Diabetic nephropathy is one of the most common and most devastating complications of diabetes. During the course of diabetic retinopathy, the glomeruli are slowly destroyed, usually with no detectable signs until the later stages of the disease, when the kidneys filtration process can no longer function. Throughout this disease, blood flow through the kidneys increases "hyperfiltration", and the kidneys become enlarged. Damage to the glomeruli becomes evident, as well as a condition known "microalbuminuria", in which a blood protein, albumin, leaks into the urine. This loss of proteins and other nutrients in the blood progresses, as does the damage to the glomeruli. The kidneys progressively lose their ability to filter waste until the final stage, kidney failure, occurs. On the other hand, some species of the plants were reported having remarkable medical importance. Trifolium alexandrinum is a medicinal herb; it has been shown to improve the flow of blood through arteries and veins in diabetic patients. Therefore, the present study aims to determine the possible improvement effects of different extracts of Trifolium alexandrinum (CF) on some biochemical and histopathological changes in the kidneys of streptozotocin-induced diabetic rats. Sixty adult male albino rats $(210 \pm 5 \mathrm{~g})$ were injected (IP) with streptozotocin (STZ) $(50 \mathrm{mg} / \mathrm{kg} \mathrm{b.wt})$ for induction of diabetes. Animals were classified into five groups. Daily intake of water, hexane and ethanolic extracts of $\mathrm{T}$. alexandrinum in drinking water for 4 weeks after diabetes induction were used. Urine glucose was detected every week. Serum total protein, albumen, urea, uric acid and creatinine levels were tested. Data were expressed statistical to elucidate the differences between treated and control groups. The kidney paraffin sections of control and treated groups were stained with haematoxylin and eosin for histological studies. A single dose of STZ induced diabetes produced remarkable effects on both structure and function of the rat kidneys. The kidney exhibited damage of some renal corpuscles revealed glomerular mesangial cells hypertrophy, dilatation of renal tubules together with necrosis of their lining cells. Serum total protein, albumen, urea, uric acid and creatinine were significantly increased. Daily urine volume and consequently renal excretion of albumen, urea, uric acid and creatinine were significantly increased. However, remarkable improvement of the renal structure and function of diabetic rats was observed after treating with Trifolium alexandrinum extracts especially the group treated with water extract.

Conclusion: Extracts of Trifolium alexandrinum improved histological and biochemical alterations of the kidneys noticed in STZ-diabetic rats. These effects may be due to the presence of a high content of flavonoids which acts synergistically as antioxidants.
\end{abstract}

Key words: Trifolium alexandrinum - kidney function - STZ-diabetic rats

\section{Introduction}

Diabetic kidney disease "diabetic nephropathy", is one of the most common and most devastating complications of diabetes. During the course of diabetic retinopathy, the glomeruli are slowly destroyed, usually with no detectable signs until the later stages of the disease, when the kidneys filtration process can no longer function. Throughout this disease, blood flow through the kidneys increases "hyperfiltration", and the kidneys become enlarged. Damage to the glomeruli becomes evident, as well as a condition known "microalbuminuria", in which a blood protein, albumin, leaks into the urine. This loss of proteins and other nutrients in the 
blood progresses, as does the damage to the glomeruli. The kidneys progressively lose their ability to filter wastes until the final stage, kidney failure, occurs. About 25 percent of people with type 1 diabetes suffer from nephropathy; those with type 2 diabetes are also at risk (Bingham and Hattersley, 2004).

Diabetes, still a significant metabolic disease, is characterized by hyperglycaemia, glucosuria, and polyuria and so on. Changes in carbohydrate and lipid metabolisms under the effect of diabetes result in atherosclerosis. Therefore, renal lesions are seen commonly in diabetic patients (Agodoa et al., 1997). Hyperglycemia and glucosuria produce osmotic diuresis and therefore polyuria. Prolonged osmotic diuresis may cause excessive urinary electrolyte loss. Disturbances in renal function are associated with several abnormalities, including proteinurea and progressive renal failure (Mayne, 1994).

Diabetic nephropathy represents a major complication of diabetes mellitus. It includes hyperfiltration and renal hypertrophy (Bardoux et al.,1999; Suanarunsawat et al., 1999; Kurusu et al., 2000; Bankir et al., 2001).

Significant increase in creatinine clearance and urinary albumin excretion was recorded in streptozotocin-induced diaetes in rats (Bardoux et al., 1999). It was suggested that vasopressin plays a critical role in diabetic hyperfiltration and albuminurea induced by diabetes mellitus. This hormone seems to be an additional risk factor for diabetic nephropathy and thus a potential target for prevention and or therapeutic intervention. Montero et al. (2000) recorded improved proteinuria and blood urea nitrogen levels in streptozotocin diabetic rats by dietary supplementation with antioxidant vitamin E (1000U/ kg diet).

Previous studies on the short-term effects of diabetes on kidney morphology have suggested cortical hypertrophy accompanied by glomerular mesangial hypertrophy (Rasch, 1979; Seyer-Hansen et al., 1980), whereas long-term diabetes caused increased glomerular basement membrane thickness (Hirose et al., 1982).

Many studies were carried out on the effects of plant extracts on diabetes induced by streptozotocin on many organs of animals (Ugochukwu and Babady,2003; Latha et al., 2004; Pari and Latha, 2004; Tan et al.,2005; Modi et al., 2006; Tunali et al., 2006). Amer et al. (2004) reported that Trifolium alexandrinum caused significant decreases in glucose and glycated hemoglobin levels and increase in insulin level and greatly improved the levels of serum lipid parameters and significantly decreased lipid peroxidation.

So the present study was designed to determine the effect of streptozotocin on some biochemical parameters and kidney histology in rats in addition to investigate the ameliorative effects of Trifolium alexandrinum extracts.

\section{Material and Methods}

\section{Preparation of extracts:}

Heads of clover flowers (Trifolium alexandrinum) were collected from fields at Hada Al-Sham, Jeddah Governorate, Suadi Arabia. Flowers were dried and ground to powder. The powder (375 g) was extracted with n-hexane in a soxhlet to give a dark brownish waxy solid (12.97 g). After that the extraction with ethanol was occured. The ethanolic solution was concentrated. After removal of ethanol, a dark greenish viscous (like molasses) $(35.83 \mathrm{~g})$ was collected.

After extraction with n-hexane and ethanol, aqueous extract was evaporated to dryness to give a dark brownish viscous (like molasses) (34.06g) (Piyachaturawat et al., 1995). For animal treatment, the hexane extract was dissolved in DMSO and suspended in distilled water while the ethanolic and aqueous extracts were dissolved in distilled water.

\section{Animals and treatments:}

Adult male albino rats $(210 \pm 5$ g $)$ were used in this study. At the start of the experiment 6 rats were kept as control and injected IP, with citrate buffer $\mathrm{pH} 4.9(1 \mathrm{ml} /$ $\mathrm{kg}$ b.wt). Sixty male rats were injected (IP) with streptozotocin (STZ) $\quad(50 \mathrm{mg} / \mathrm{kg} \mathrm{b.wt})$ (Sigma chemical Co. P.0. Box 14508 St. Louis, MO 63178 USA) according to Suanarunsawat et al. (1999). All rats were examined by Uri- Quick TM (cline - 3, 
reagent strips for urine analysis) for glucose detection. Rats 200: $400 \mathrm{mg}$ glucose/ dl were considered diabetic and used in the experiment. The diabetic rats were classified into four groups six rats each group. The solutions of the flower extracts were freshly prepared and were administered to rats in drinking water for 4 weeks. Hexane extract was administered in a dose of $(50 \mathrm{mg} / \mathrm{kg}$ b.wt $)$, whereas ethanolic and aqueous extracts at $(100 \mathrm{mg} /$

kg b. wt) (Amer et al.,2004).

All rats were housed individually for urine collection in a stainless steel metabolic cage under fasting conditions for 24 hours. Urine was frozen at $-20 \mathrm{C}$ till analysis. Urine glucose was detected every week in all rats. Rats were fasted 12 hours before sacrificing.

\section{Blood sampling:}

Blood was collected from the jugular vein. Serum was seperated by centrifugation (3000 rpm for 15 111in) and kept quickly in Expender tube at $-20{ }^{\circ} \mathrm{C}$ till analysis.

\section{Biochemical analysis:}

Serum total protein was determined according to Lowery et al.(1951), serum and urine albumin was detected according the method of Doumas et al. (1971). Urea (serum \& urine) was estimated by the technique of Chaney et al. (1962), uric acid (serum \& urine) was determined by using the method of Haisman and Muller (1977) and creatinine was tested according to the methods of Folin (1934).

\section{Histological study:}

The kidney of animals of all groups were dissected and small pieces were fixed in $10 \%$ formol saline, dehydrated in ascending grades of ethyl alcohol, cleared in xylol and mounted in molten paraplast at $56-60^{\circ} \mathrm{C}$ and cut at $5 \mu \mathrm{m}$ on a rotary microtome. The paraffin sections were stained with haematoxylin and eosin for histological studies and examined under light Leitz microscope.

\section{Statistical analysis:}

Means and standard deviations were calculated for each group and data were analyzed using Student's $t$-test (Snedecor and Cochran, 1967). The conventional level of $5 \%$ was taken as the level of significance.

\section{Results}

The effects of treatment with hexane, ethanol and water extracts of CF on serum total protein, albumen, urea, uric acid and creatinine of diabetic rats are shown in table (1). Significant increases $(P<0.05)$ in all tested parameters were observed in the diabetic group compared to control group. This general increase in all parameters was ameliorated by the treatment with $\mathrm{CF}$ extracts although serum total protein and creatinine of $\mathrm{CF}$ extracts treated groups were not significantly different from both control and diabetic groups.

Daily urine volume and excretion of albumin, urea, uric acid and creatinine were significantly increased $(P<0.05)$ in diabetic group compared to control group (table 2 ). Treatment with hexane and ethanol extracts of $\mathrm{CF}$ provided some improvement to the daily excretion of the previous parameters. Moreover no signifi-cant difference was found between control group and CF-water extract treated group (table 2).

The kidney of control rats exhibited the classical histological appearance that is essentially formed of nephric units. Each unit is formed of Malpighian corpuscle, convoluted and collecting tubules. Malpigian corpuscle consists of spherical Bowman's capsule; its wall is formed of simple squamous epithelium surrounding a capillary network or glomerulus (Fig.1). Meanwhile, the kidney of streptozotocindiabetic rats showed pathological changes such as damage of some renal corpuscles revealed glomerular mesangial cells hypertrophy and proliferation, the glomerular capillaries entirely filling the renal corpuscle as well as damage of squamous epithelium of Bowman's capsule (Fig.2). Furthermore there were dilatations of renal tubules especially the proximal one resulting in a decrease in the interstitial tissue. Also, loss of tubules characteristic appearance was observed due to cloudy swelling, nuclear degeneration and necrosis of its lining cells (Fig.3). 
However the administration of $\mathrm{CF}$ extracts to diabetic rats exhibited an improvement of the occurred renal histopathological changes in the diabetic rats. This achieved by the glomerular and tubular features, a moderate degree of kidney cell degeneration in addtion to the recovery of ther kidney towards normal was noticeable (Figs. 4,5,6).

Table (1): Effect of hexane, ethanol and water extracts of CF on serum total protein, albumin, urea, uric acid and creatinine of streptozotocin-induced diabetic rats.

\begin{tabular}{|l|c|c|c|c|c|}
\hline \multicolumn{1}{|c|}{ Groups } & Control & Diabetic & $\begin{array}{c}\text { Diabetic+CF } \\
\text { Hexane extract }\end{array}$ & $\begin{array}{c}\text { Diabetic+CF } \\
\text { Ethanol extract }\end{array}$ & $\begin{array}{c}\text { Diabetic+CF } \\
\text { Water extract }\end{array}$ \\
\hline \hline Parameters & & & & & \\
\hline Total protein & 6.8 & $7.84^{\mathrm{a}}$ & 6.88 & 7.22 & 6.98 \\
(g/dl) & \pm 0.44 & \pm 0.53 & \pm 0.67 & \pm 0.53 & \pm 0.37 \\
\hline Albumin & 4.7 & $7.02 \mathrm{a}$ & $6.1^{\mathrm{a}}$ & $6.92^{\mathrm{a}}$ & $6.84^{\mathrm{a}}$ \\
(g/dl) & \pm 0.36 & \pm 0.72 & \pm 0.51 & \pm 0.83 & \pm 0.66 \\
\hline Urea & 35.0 & $45.6^{\mathrm{a}}$ & $40.4^{\mathrm{ab}}$ & $44.4^{\mathrm{a}}$ & $41.0^{\mathrm{b}}$ \\
(mg/dl) & \pm 3.69 & \pm 6.28 & \pm 2.15 & \pm 2.15 & \pm 2.61 \\
\hline Uric acid & $3.64 \pm 0.55$ & $5.6^{\mathrm{a}}$ & $4.0^{\mathrm{b}}$ & $5.0^{\mathrm{a}}$ & $4.16^{\mathrm{b}}$ \\
(mg/dl) & \pm 0.48 & \pm 0.32 & \pm 0.36 & \pm 0.41 \\
\hline Creatinine & $0.72 \pm 0.12$ & $1.04^{\mathrm{a}} \pm 0.16$ & 0.84 & 0.92 & 0.88 \\
(mg/dl) & & \pm 0.10 & \pm 0.17 & \pm 0.17 \\
\hline
\end{tabular}

Values are expressed as means \pm SD.

(a) Significant at $\mathrm{P}<0.05$ as compared to control

(b) Significant at $\mathrm{P}<0.05$ as compared to diabetic group.

Table (2): Effect of hexane, ethanol and water extracts of $\mathrm{CF}$ on 24h urine volume, albumin, urea, uric acid and creatinine of streptozotocin-induced diabetic rats.

\begin{tabular}{|l|c|c|c|c|c|}
\hline \multicolumn{1}{|c|}{ Groups } & Control & Diabetic & $\begin{array}{c}\text { Diabetic+CF } \\
\text { Hexane extract }\end{array}$ & $\begin{array}{c}\text { Diabetic+CF } \\
\text { Ethanol extract }\end{array}$ & $\begin{array}{c}\text { Diabetic+CF } \\
\text { Water extract }\end{array}$ \\
\hline \hline Parameters & & & & & \\
Urine volume & 17.64 & $42.12^{\mathrm{a}}$ & $29.94^{\mathrm{ab}}$ & $27.84^{\mathrm{ab}}$ & $20.10^{\mathrm{b}}$ \\
(ml/day) & \pm 3.8 & \pm 5.72 & \pm 12.46 & \pm 9.78 & \pm 6.66 \\
\hline Albumin & 0.60 & $1.50^{\mathrm{a}}$ & $1.08^{\mathrm{a}}$ & $1.06^{\mathrm{a}}$ & $0.77^{\mathrm{b}}$ \\
(mg/day) & \pm 0.07 & \pm 0.4 & \pm 0.25 & \pm 0.31 & \pm 0.17 \\
\hline Urea & 0.23 & $0.56^{\mathrm{a}}$ & $0.50 \mathrm{a}$ & $0.46 \mathrm{a}$ & $0.32^{\mathrm{b}}$ \\
(mg/day) & \pm 0.04 & $\pm 0,06$ & \pm 0.08 & \pm 0.06 & \pm 0.05 \\
\hline Uric acid & $0.03 \pm 0.01$ & $0.11^{\mathrm{a}}$ & $0.10^{\mathrm{a}}$ & $0.08^{\mathrm{a}}$ & $0.04^{\mathrm{b}}$ \\
(mg/day) & \pm 0.02 & \pm 0.03 & \pm 0.02 & \pm 0.01 \\
\hline Creatinine & $0.10 \pm 0.03$ & $0.24^{\mathrm{a}} \pm 0.11$ & $0.25^{\mathrm{a}}$ & $0.22^{\mathrm{a}}$ & $0.15^{\mathrm{b}}$ \\
(mg/day) & & \pm 0.09 & \pm 0.05 & \pm 0.05 \\
\hline
\end{tabular}

Values are expressed as means \pm . SD.

(a) Significant at $\mathrm{P}<0.05$ as compared to control

(b) Significant at $\mathrm{P}<0.05$ as compared to diabetic group. 

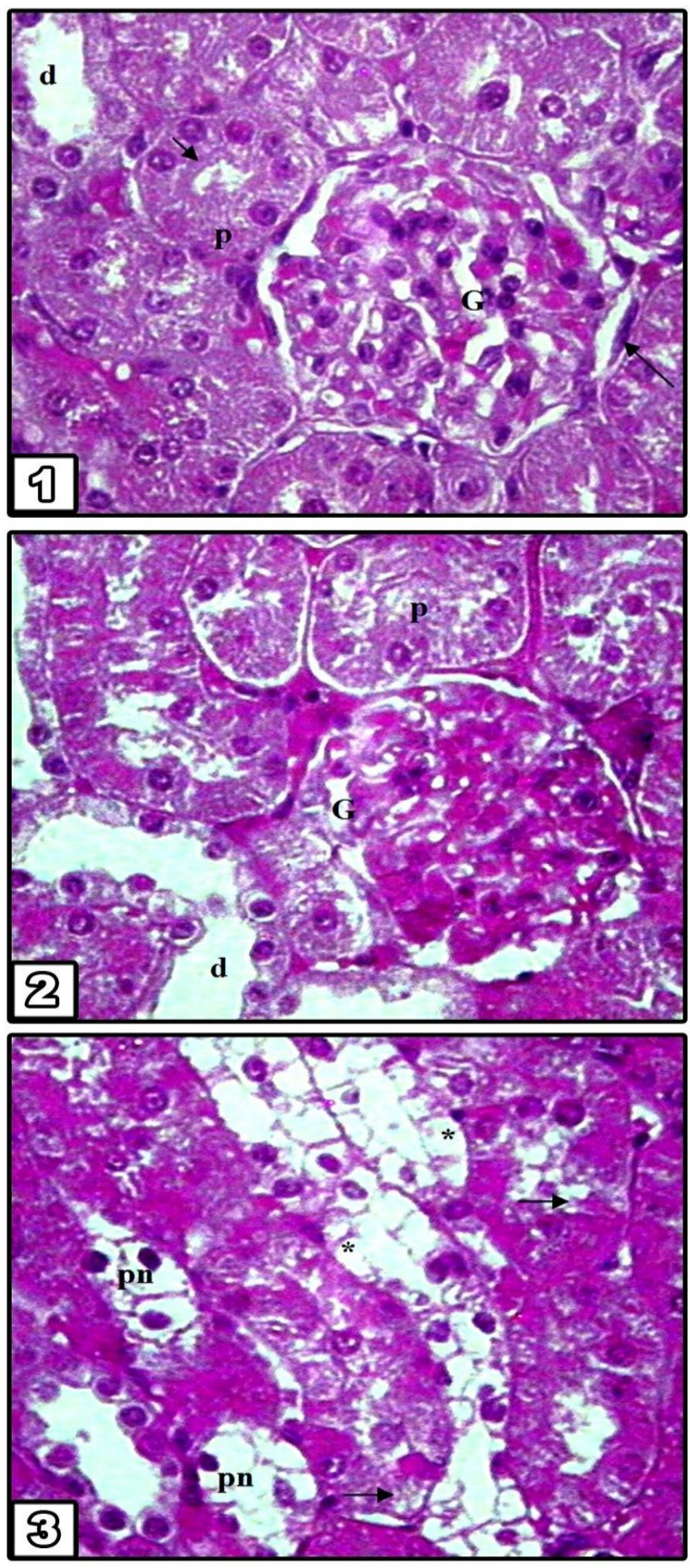

Fig.I. Section in the rat kidney of control group showing renal corpuscle, glomerulus $(\mathrm{G})$, squamous epithelium cells of Bowman's capsule (arrow). Proximal (p) tubules with brush border (head arrow) and distal (d) tubules

Fig.2. Section in the rat kidney of diabetic group showing glomerular $(\mathrm{G})$ mesangial cell hypertrophy, damage of squamous epitheliul cells of Bowman's capsule. Dilatation in renal tubules, especially the proximal ones (p), with decrease of the interstitial tissue

(X 400).

Fig.3. Section in the rat kidney of diabetic group showing dilated renal tubules. Degeneration oflining cells $(*)$, cytoplasmic vacuolations (arrow), pyknotic nuclei (pn) (X 400). 

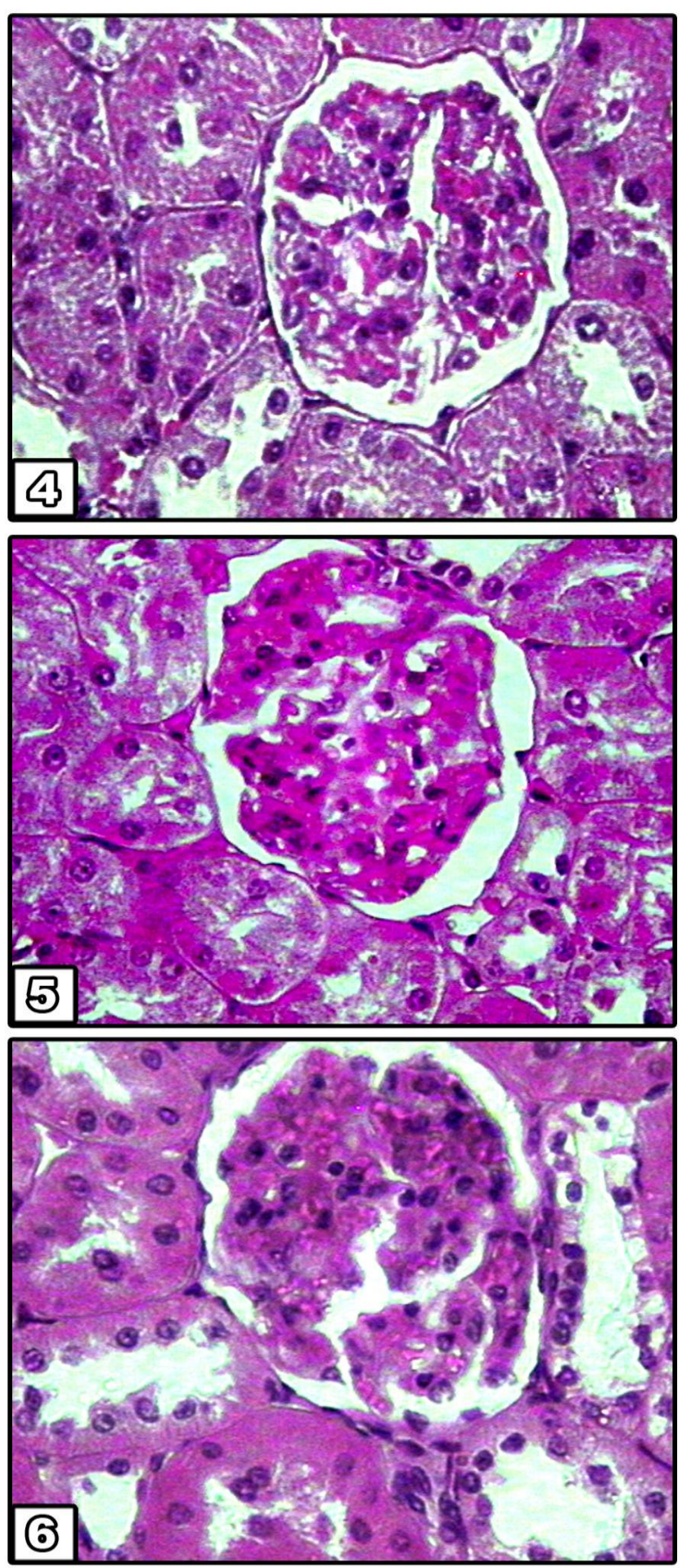

Fig.4. Section in the rat kidney of diabetic \& clover flowers hexane extract group showing less hypertrophy of glomerular mesangial cells and pyknotic nuclei of some renal tubules cells (X 400).

Fig.5. Section in the rat kidney of diabetic \& clover flowers ethanol extract group showing less proliferation of glomerular mesangial cells. Less dilated renal tubules

(X 400).

Fig.6. Section in the rat kidney of diabetic \& clover flowers water extract group showing less degree of kidney cell degeneration. Renal tubules reveal almost normal appearance

(X400). 


\section{Discussion}

Insulin-dependent diabetes is usually accompanied by high urinary glucose concentration, which produces an osmotic diuresis and therefore polyuria. Abnormalities in lipid and protein metabolism including enhanced lipolysis and increased breakdown of protein may be secondary to insulin deficiency (Mayne, 1994).

The presence of renal damage becomes rapidly noticeable due to changes in two important functions of the kidney: the formation of urine and the reabsorbtion of substances. One of the first phenomena that can be observed following renal injury is a change in the composition of the urine. The kidneys may excrete more water (polyuria) or less water (oligouria). The first condition may occur, because the kidney has lost its concentrating capacity and the second because the filtrate leaks back into the blood. Interference with the reabsorptive capacity of the kidney will be become manifested in the excretion of certain substances in the urine, such as glucose. If the damage is such that cellular structure is broken down, protein will be present in the urine as a result. Excretion of protein may however also be indicative of reduced reabsorptive capacity.

Renal function is also tested by the concentration of urea in the blood. This concentration is increased if renal function is severely impaired; measuring creatinine clearance also assesses the efficiency of renal function.

In this study, the observed urinary content abnormalities in STZ-induced diabetic rats including proteinurea and increase urine concentration of albumin, urea, uric acid and creatinine are in agreement with previous studies, usually associated with an increased risk of developing progressive renal diseases (Bardoux et al., 1999; Suanarunsawat et al., 1999; Kurusu et al., 2000; Bankir et al., 2001).

Previous study suggested proliferation and hypertrophy in the glomerular and tubular regions of the renal cortex in the diabetes (Huseyin et al., 2001). They reported glomerular basement membrane thickness, an increase in the mesangial volumes and hypertrophy in renal cortical structures following short-time experimental diabetes in rabbit. Also, Berg et al. (2003) reported similar findings in the kidney of rat by ultrastructure study, These changes include degeneration and dilatation of cells of the renal tubules with narrowing of interstitial area and increased number of mesangial cell indicating proliferation in the glomerular capillaries following two months of experimentally-induced diabetes.

On the other hand, the present results suggest that the water, hexane and ethanol extracts from the flower head of Trifolium alexandrinum could exert antidiabetic activities. Similarly, Salem et al. (2002) and Amer et al.(2004) reported remarkable improvement of biochemical alterations noticed in STZ-diabetic rats after treating rats with $\mathrm{CF}$ extracts especially the group treated with water extract. These effects may be due to the presence of a high content of flavonoids which act synergistically as antioxidants (Mohamed et al., 2000; Latha et al.,2004; Modi et al., 2006).

In conclusion, the histological and biochemical findings pointed out remarkable improvement to all these abnormalities by treating with the flower extracts of Trifolium alexandrinum. This suggests the needs to excessive studies on this plant to explore its active ingredients to be used for preparing a complimentary treatment for diabetes mellitus.

\section{References}

1. Agodoa L, Eknoyan G, Ingjlfing J, Keane W and Mitch W. (1997): Assessment of structure and function in progressive renal disease. Kidney Int., 63: 144- 150.

2. Amer M, El-Habibi S and El-Gendy A. (2004): Effects of Trifolium alexandrinum extracts on streptozotocin-induced diabetes in male rats. Ann. Nutr. Metab., 48 (5): 343-347.

3. Bankir L, Bardoux $\mathbf{P}$, and Ahloulay $M$. (2001): Vasopressin and diabetes mellitus. Nephron, 87(1): 8-18.

4. Bardoux P, Martin H, Ahloulay M, Bouby N, Trinh-Trang-Tan $M$ and Bankir L. (1999): Vasopressin contributes to hyperfiltration, albuminuria and renal hypertrophy in diabetes mellitus: study in 
vasopressin deficient Brattleboro rats. ProcNatl.Acad. Sci.USA, 96 (18): 10397-10402.

5. Berg T. (2003): Renal ultrastructure in experimental diabetes mellitus. J. Med. Sci., 46: 661-665.

6. Bingham I C and Hattersley A. (2004): Renal cysts and diabetes syndrome resulting from mutations in hepatocyte nuclear factor-1B. Nephrol Dial Transplant., 19 (11): 2703-2708.

7. Chaney A, Marbanch $\mathbf{C}$ and Faweett $\mathbf{J}$. (1962): A colorimetric method for determination of blood urea. J. Clin. Chem., 8: 130-135.

8. Doumas $B$, Watson $W$ and Biggs $H$. (1971): Albumin standards and the measurement of serum albumin with bromocresol green. Clin. Chem. Acta., 31:87-90.

9. Folin O. A (1934): Colourimetric determination of serum creatinine. Phys. Chem., 268: 228-234.

10. Haisman $P$ and Muller B. (1977): Glossary of clinical chemistry terms Butterworth, London PP. 126.

11. Hirose, K; Nozawa, M and Gunderson, H. (1982): Development of glomerular lesions in experimental long-term diabetes in the rat Kidney. Int., 21: 689-695.

12. Hoseyin B, Bilge O, Kaloglu C, Ozdemir $O$ and Ayan S. (2001): Effects of experimental diabetes and insulin treatment on rabbit renal morphology: A quantitative and qualitative study.J. Med. Sci., 31: 209- 216.

13. Kurusu A, Shon 1, Nakamura S, Fukui M, Shirato I and Tomino Y. (2000): Effects of the new hydoxy-3 methylglutaryl coenzyme a reductase inhibitor fluvastain on anti-oxidant enzyme activities and renal function in streptozotocin-indued diabetic rats. Clin. Exp. Pharmacol. Physiol., 27( I 0): 767-770.

14. Latha M, Pari L, Sitasawd S and Bhonde R. (2004): Scoparia dulcis, a traditional antidiabetic plant, protects against stmptozotocin induced oxidative stress and apoptosis in vitro and in vivo. Biochem. Mol. Toxicol., 18 (5): 261-272.

15. Lowry O, Rosebrouch N, Fan A and Randall B. (1951): Protein measurement with the folin phenol reagent. Am. J. Clin. Pathol.,16: 40-44.

16. Mayne P. (1994): Clinical chemistry in diagnosis and treatment. $6^{\text {th }}$ ed. Edward Arnold. London. Boston, Melbourne, Auckland: 189.

17. Modi K, Santani D, Goyal $\mathbf{R}$ and Bhatt P. (2006): Effect of coenzyme Q10 on catalase activity and other antioxidant pammeters in streptozotocin-induced diabetic rats. Biol. Trace. Elem. Res., 109(1): 25-34.
18. Mohamed K, Hassanean H, Ohtani K, Kasai R and Kazuo Y. (2000): Chalcanol glucosides from seeds of Trifolium alexandrinum. Phytochem. 53 (3):401-404.

19. Montero A, Munger $\mathbf{K}$, Khan $\mathbf{R}$, Valdhielso J, Morrow J, Guash A, Ziyadeh F and Badr K. F (2000): (2)Isoprostanes mediate high glucose induced TG F -beta synthesis and glomerular proteinurea in experimental type 1 diabetes. Kidney Int., 58 (5):1963-1972.

20. Pari L and Latha M. (2004): Protective role of Scoparia dulcis plant extract on brain antioxidant status and lipidperoxidation in STZ diabetic male Wistar rats BMCComplement.Altern.Med.,2(4):16- 21.

21. Piyachaturawat $\mathbf{P}$, Ercharuporn $\mathbf{S}$ and Suksamrarn A. (1995): Uterotrophic effect of Curcuma comosa in rats. Int. J. Pharmacognosy., 33 (4): 334-338.

22. Rasch R. (1979): Prevention of diabetic glomerulopathy in streptozotocin diabetic rats by insulin treatment. The mesangial regions Diabetologia., 17: 243-248.

23. Salem M, El-Gendy A and Tohami A. (2002): Effect of some flower extracts of Egyptian clover (Trifolium alexandrinum) on renal function of induced diabetic albino rats. Sc. J. Az. Med. Fac., (Girls). 23 (3): 83-91.

24. Seyer- Hansen K, Hansen $J$ and Gundersen H. (1980): Renal hypertrophy in experimental diabetes. Diabetologia., 18: 501-505.

25. Snedecor G and Cochran W. (1967): Statistical methods Low State University Press. Ames. Iowa: 59-60.

26. Suanarunsawat T, Klongpanichapak $\mathbf{S}$ and Chaiyabutr N. (1999): Role of nitric oxide in renal function in rats with short and prolonged periods of streptozotocininduced diabetes. Diabetes Obes. Metab., 1(6): 339-346.

27. Tan B, Tan C and Pushparai P. (2005): Ant-diabetic activity of the semi-purified fractions of Averrhoa bilimbi in high fat diet fed-streptolotocin-induced diabetic rats. Life Sci., 76(24): 2827-2839.

28. Tunali S and Yanardag R. (2006): Effect of vanadyl sulfate on the status of lipid parameters and on stomach and spleen tissues of streptozotocin-induced diabetic rats. Pharmacol. Res. 53 (3): 271-277.

29. Ugochukwu N and Babady N. (2003): Antihyperglycemic effect of aqueous and ethanolic extracts of Gongronema latifolium leaves on glucose and glycogen metabolism in livers of normal and streptozotocin-induced diabetic rats. Life Sci., 73 (15): 1925-1938. 


\section{تأثير مستخلصات زهور البرسيم على الكلى في ذكور الجرذان المصابة بالسكر: دراسات بيوكيميائية ونسيجية فيورية}

\section{ميسـاء محمد الراوي}

قسم الأحياء ـ كلية التربية الأقسام العلمية للبنات ـ مكة المكرمة

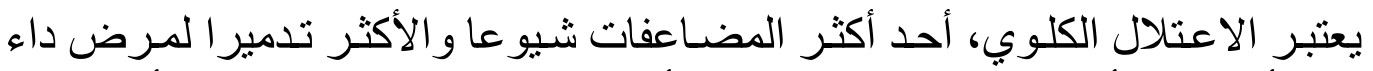

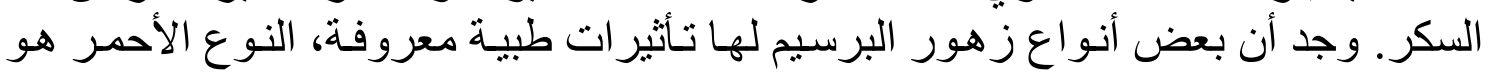

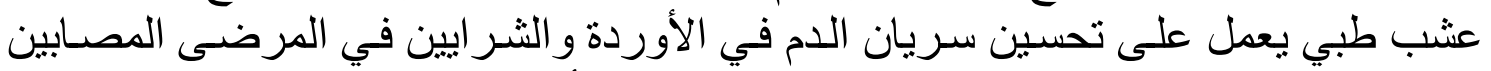

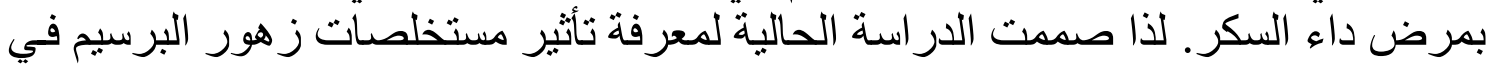

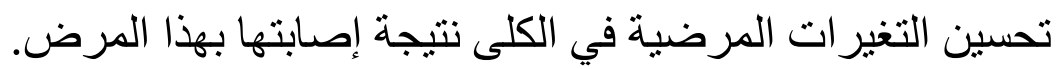

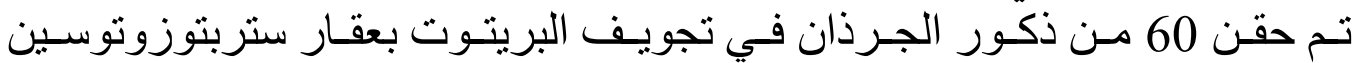

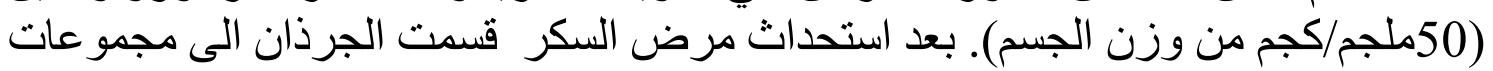

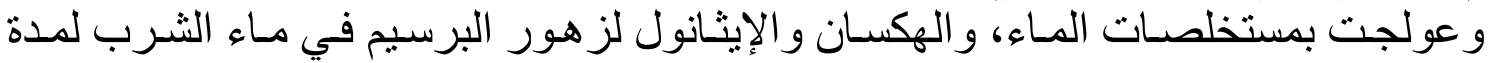

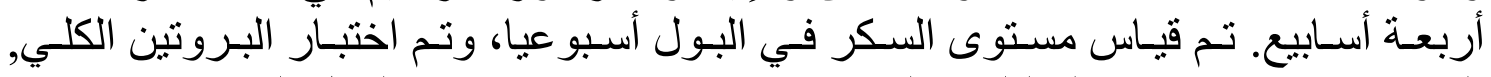

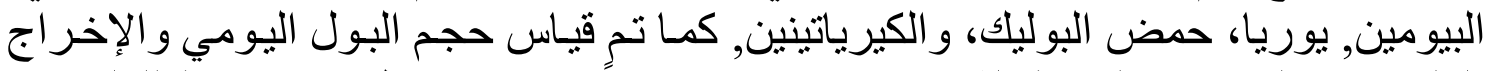

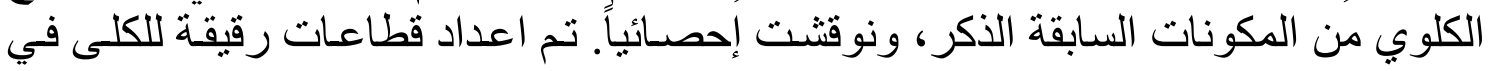

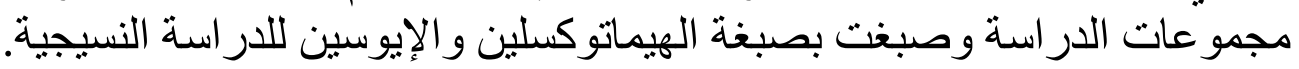

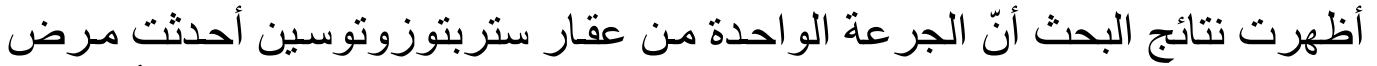

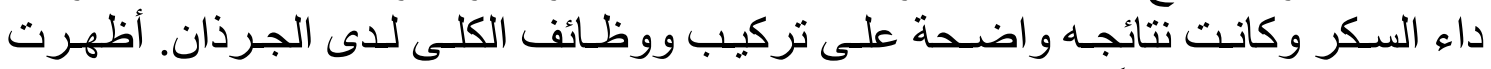

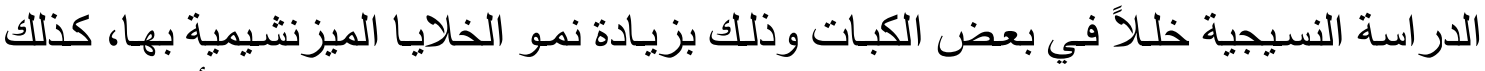

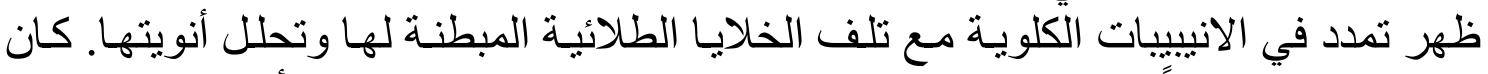

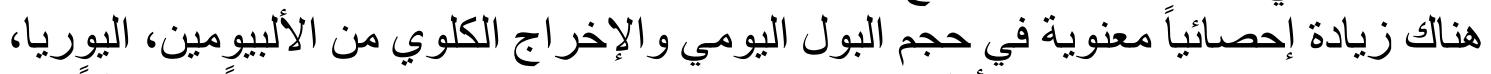

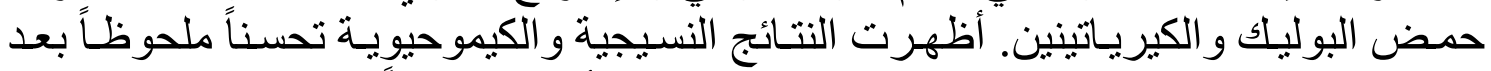

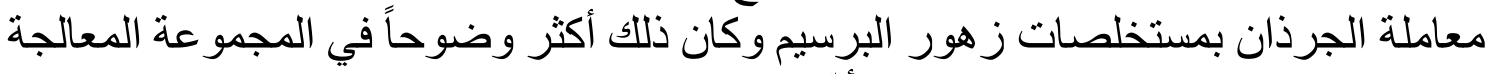

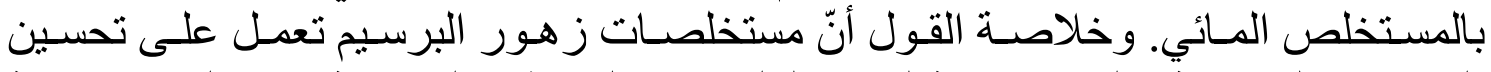

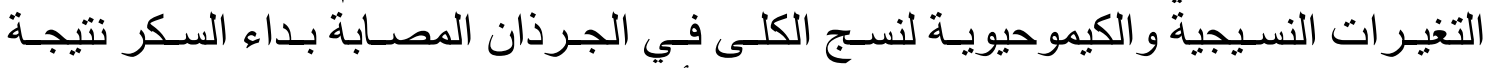

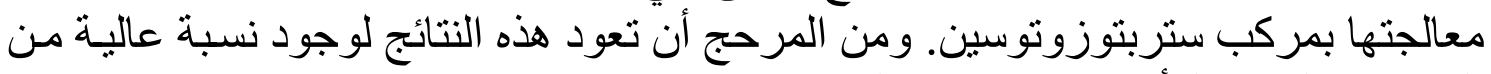
المكونات المانعة للأكسدة في ز هور البرسير. 